\title{
ILO: Grev Hakkına İlişkin Kriz
}

\author{
SEVDA KÖSE* \\ sevdakose@gmail.com \\ ORCID ID: 0000-0001-7751-3240
}

\begin{abstract}
Öz: Bu çalışmanın amacı, 2012 yılında Uluslararası Çalışma Örgütü Konferansındaki işveren grubunun grev hakkı ile ilgili yaptığı sert itirazların Uluslararası Çalışma Örgütü (ILO) bağlamında bir krize yol açıp açmadiğının incelenmesidir. ILO ve denetim mekanizmaları aracılı̆̆ ile oluşturulan içtihatlar bağlamında 60 yıl boyunca grev hakkına, örgütlenme özgürlüğünün bir parçası olarak yer verilerek, toplu sözleşme, sendika hakkı ve grev hakkı bir bütün olarak düşünülmüştür. Bu içtihatların, grev hakkının uluslararası alanda tanınmasına olan katkısi fazladır. Bu durum ta ki 2012 yılındaki ILO Konferansina kadar devam etmiştir. İşveren grubundan ciddi bir itiraz ile birlikte grev hakkı ile ilgili ILO'da bir kriz olup olmadığ 1 sorusu gündeme gelmeye başlamıştır. Bu durum ILO’nun denetim mekanizmasının etkinliğinin sorgulanmasına neden olurken aynı zamanda ILO’nun denetim organları içindeki eşgüdümün de eleştirilmesine yol açmıştır.
\end{abstract}

Anahtar kelimeler: Grev hakkı, Örgütlenme özgürlüğü, Uluslararası Çalışma Örgütü, ILO krizi, Sendika özgürlüğ̈̈.

\section{Giriş}

Grev hakkını uluslararası alanda anlamlandırmaya ve etkin hale getirmeye çalışan en önemli mekanizmalardan birisi Uluslararası Çalışma Örgütüdür. Örgütlenme özgürlüğü ve toplu pazarlık hakkı ile bir bütünü oluşturan grev hakkı bizzat Uluslararası Çalışma Örgütü'nün yapısında kutsal bir yeri olan konulardan birisidir, ancak bu hak uluslararası çalışma hukuku alanında sadece Uluslararası Çalışma Örgütü (ILO) ile sınırlandırılamamaktadır. Bu bağlamda Uluslararası Çalışma Örgütü öncü bir görev görse de evrensel ve bölgesel ölçekte (İnsan Hakları Evrensel Bildirgesi, Birleşmiş Milletler İkiz Sözleşmeleri, İnsan Hakları Avrupa Sözleşmesi, Avrupa Sosyal Şartı gibi benzeri belgelerde) de bu konu ele alınmaktadır. Sendika Özgürlüğü ve Sendika Hakkı'nın Korunması Sözleşmesi olan 87 Sayılı ILO Sözleşmesi’nin metninde grev hakkı açıkça yer almamış olsa dahi ILO’nun denetim organları Sendika Özgürlüğü Komitesi ve Uzmanlar Komitesi toplu pazarlık ve grev hakkı ile sendika hakkının birbirinin varlık koşulu olduğunu uzun yıllardır vermiş olduğu kararlarında vurgu-

\footnotetext{
* Dr., Kocaeli Üniversitesi, İIBF, Çalışma Ekonomisi ve Endüstri İlişkileri Bölümü.
} 
lamaktadır. Bu bakımdan sendikal hakların bütünselliği ve bölünmezliğinin uluslararası çalışma hukukunun temel ilkelerinden biri olduğunu söylemek mümkündür.

Çalı̧̧mada grev hakkı ile ilgili krizin çıktığı yıl olan 2012 ve devamındaki yıllardaki ILO Konferansı Yönetim Kurulu Raporları ve ILO Denetim Organlarının raporları incelenmiştir. Grev hakkı ile ilgili kriz tartışmasında ILO’nun üçlü yapısı bağlamında tarafların bakış açılarındaki farklılığın ortaya konulması istenmiştir.

\section{Uluslararası Çalışma Örgütü}

Çalışanların uluslararası alanda bir korumaya ihtiyacı olduğu fikrinin temelleri, sanayileşmenin hız kazanması ile insan onuruna yakışmayan kötü çalışma koşullarının çok yoğun şekilde var olduğu dönemde atılmıştır. 20. yüzyılın başlarında çalışanların haklarını korumak için küresel bir örgüte ihtiyaç olduğu fikri ortaya çıkmışıır'. Bu fikir Birinci Dünya Savaşı’nın sonunda daha da canlanmıştır. Buradaki önemli vurgulardan birisi emeğin bir mal olmadığıdır. 25 Ocak 1919 tarihinde Versay Barış Konferansı, ABD, Japonya, İngiltere, Fransa, İtalya, Belçika, Polonya ve Çekoslavakya temsilcilerinden oluşan bir komisyon kurar. Bu komisyona, işçilerin çalışma koşulları ile bu konuda ahengin sağlanabilmesini araştıracak bir kuruluşun kurulması konusunda önerilerde bulunma görevini üstlenir ${ }^{2}$. Bu temel ihtiyaçtan hareketle Uluslararası Çalışma Örgütü 1919 yılında Versay Antlaşması bağlamında kurulmuştur._ILO’nun özgün ve en önemli görevi uluslararası çalışma standartlarının düzenlenmesi, geliştirilmesi ve izlenmesidir. ILO evrensel ve kalıcı bir barışın ancak sosyal adalet temeli üzerine kurulabileceğine inanmaktadır. Bu bağlamda insan haklarının korunması ve çalışma haklarının iyileştirilmesi ILO’nun temel felsefelerinden birisidir ${ }^{3}$.

Uluslararası Çalı̧̧ma Örgütünün amacına bakıldığında ise temelde ikinci kuşak insan haklarını düzenleyen sözleşme ve tavsiyelerin yer aldığı bir uluslararası kurallar sistemi oluşturmak ve bu kuralların uygulanmasını sağlamak olduğu görülebilmektedir. İnsan hakları birinci kuşak, ikinci kuşak ve üçüncü kuşak insan hakları olarak sinıflandırılabilmektedir. Bu bağlamda ILO’nun sözleşme ve tavsiye kararlarının odak noktasını ikinci kuşak haklar oluşturmaktadır. Kuşaklar arasında yapılan sınıflandırmada da devlet ile insan hakları arasındaki ilişkinin niteliği ve ne olması gerektiğine değinilmekle birlikte tarihsel süreç ön plana çıkartılmıştır. Birinci kuşak haklar, siyasal ve kişisel haklar, ikinci kuşak haklar ekonomik ve sosyal haklar, üçüncü kuşak haklar ise çevre geliştirme ve barış haklarıdır. Birinci kuşak haklar, iktidar karşısında ve diğer kişiler karşısında bireyin güvenliğini ve özerkliğini sağlayan haklardır. Düşünce özgürlüğü, ifade ve iletişim özgürlüğü başlıcalarıdır. İkinci kuşak haklar, sosyal, iktisadi ve kültürel haklar ve özgürlüklerdir. 19. yüzyılda eşitlik ve özgürlük herkese tanınmış olsa da bunlardan sadece küçük bir kesim faydalanabilmekte olduğu belirtilmektedir. Bu dönemde yaşanan toplumsal sefalet ve işçilerin içinde

1 Mesut Gülmez, Uluslararası Sosyal Politika, Ankara: Hatipoğlu Yayınclık, 2011, s.3.

2 Tankut Centel, Türkiye’nin Onayladığı ILO Sözleşmeleri, İstanbul: Mess, 1999, s.1.

3 Pir Ali Kaya, Uluslararası Sosyal Politika: Teorisi, Uluslararası Çalışma Normları ve Güncel Gelişmeler, Bursa: Siyasal Kitabevi, 2014, s.35. 
bulunduğu güç koşullar bunların en belirgin kanıtları olduğu düşünülebilmektedir. Sendikal hak ve özgürlükler, çalışma hakkı, sosyal güvenlik hakkı ve benzeri haklar ikinci kuşak haklar kapsamında yer almaktadır ${ }^{4}$. İkinci kuşak haklar denildiğinde Uluslararası Çalışma Örgütü, sanayileşme süreci ile başlayan kötü çalışma koşullarından etkilenen kesimleri koruma amacıyla başladığı uluslararası kural üretme etkinliğini son yıllarda daha da genişleterek küreselleşmenin ortaya çıkardığı sorunlara da yönelmiştir ${ }^{5}$.

Demokratik değerlerin ortaya çıkışı ve korunması Uluslararası Çalışma Örgütü için son zamanlarda ortaya çıkan bir gelişme değildir. Kurulduğu günden bu güne bu değerlerin birçoğu ILO'da önemli bir yere sahiptir. Evrensellik ilkesi bağlamında ILO’nun politik, yasal ve ekonomik açıdan birbirinden farklı ülkelerle çalıştığ 1 görülmektedir. Üçlü yapısı içinde bu farklı değerleri ortak bir zeminde uzlaştırmaya çalışan ILO'da sivil ve siyasi hakların yeri çok önemlidir. Sivil ve siyasi haklar olmaksızın ne sendikal haklar olağan şekilde uygulanabilir ne de çalışanların hakları savunulabileceği düşünülmektedir ${ }^{6}$. ILO Birleşmiş Milletler sistemi içinde üçlü yapıya sahip önemli ve yegane bir uluslararası organdır. ILO'nun en ayırt edici özelliği olarak düşünülebilen üçlülük ilkesi, ILO’yu evrensel ve bölgesel düzeydeki tüm uluslararası kuruluşlardan ayırmaktadır. İşçi ve işveren temsilcileri politika ve programların şekillenmesinde üçüncü tarafı oluşturan hükumet temsilcileri ile eşit söz hakkına sahiptir. ILO, bu yapıyı üye ülkelere de önermektedir ${ }^{7}$. Her ikisi de anayasal bir ilke olan sendika özgürlüğü ile üçlü yapı arasında önemli bir bağın olduğu belirtilmektedir. Bu bağlamda üçlülük ilkesinin özünü geniş anlamda sendikal hak ve özgürlüklerin oluşturduğu vurgusu yapılmaktadır. Sendikal hak ve özgürlüklerin bir bütün olarak tanınmaması, üçlülük ilkesinin anlamını kaybetmesine sebep olacağ 1 ifade edilmektedir ${ }^{8}$.

İnsan Hakları Evrensel Bildirgesi'nin 23. Maddesinin 4. fıkrası, “herkesin çıkarlarını korumak için sendika kurma ve sendikaya üye olma hakkına sahip olduğunu” belirtir. $\mathrm{Bu}$ hakkın daha spesifik bir görünümü ise 20. Maddede yer almaktadır. 20. Madde ise barış̧ıl toplanma ve örgütlenme hakkından söz etmektedir'. Evrensel Bildiri'de bu prensibin kapsamı ILO'nun 3 önemli aracında da yer almaktadır. Bunlardan ilki ILO Anayasasıdır. Anayasa’nın başlangıç bölümünde örgütlenme özgürlügüünden söz edilmektedir. Anayasanın girişi açıkça çalışma koşullarını geliştiren ve bu sayede çalışma barışını sağlayan önlemler arasında sendikal hakları da saymaktadır. ILO'nun ikinci önemli temel belgesi Philedelphia Bildirgesi 1944'te kabul edilmiş ve 1946 'da ILO Anayasasına dahil edilmiştir. Philedelphia Bildirgesi gerekli ve sürdürülebilir bir gelişme olarak karakterize edilen ve ILO’nun dayandığı temel prensiplerden birisi

4 İbrahim Kaboğlu, Özgürlükler Hukuku, 6. Baskı, Ankara: İmge Kitabevi, 2002, s.39-40.

5 Gülmez, Uluslararası Sosyal Politika, s.9.

6 ILO, Report of Director-General, Democratisation and the ILO, Geneva: International Labour Conference, $79^{\text {th }}$ Session, 1992 , s.24.

7 Kaya, Uluslararası Sosyal Politika, s.36.

8 Mesut Gülmez, Sendikal Hakların Ulusal Üstü Kuralları, Oluşumu ve Uygulanması, 2. Baskı, Ankara: Hatiboğlu Basım ve Yayın, 2014, s.54.

9 Mehmet Semih Gemalmaz, Ulusalüstü İnsan Hakları Belgeleri II.Cilt Uluslararası Sistemler, Ankara: Legal, 2010, s.14. 
olarak örgütlenme özgürlüğünden yeniden bahsetmiştir. Örgütlenme özgürlüğü ile ilgili üçüncü belge ise 87 sayılı ILO sözleşmesidir ${ }^{10}$.

Örgütlenme hakkının özel bir şekli olan ve insan hakları belgelerinde tanınıp güvence altına alınan sendika hakkı ve toplu pazarlık ile grev haklarının uluslararası alanda kabulü ILO’nun Anayasası ve özellikle II. Dünya Savaşı sonrası kabul ettiği sözleşmeler ile gerçekleşebilmiştir ${ }^{11}$. Bu konuda ILO'nun sahip olduğu misyona göre geç bir tarihte yani kurulduktan yaklaşı 30 yıl sonra sendika özgürlüğü ve toplu pazarlıkla ilgili sözleşmeleri kabul etmiş olduğu görülmektedir.

Sendikalar da örgütlenme özgürlüğünün tanınmasını, ILO’nun kurulmasından önce de talep etmekteydiler. İnsan haklarının ayrılmaz bir parçası bağlamında çalışanların haklarının korunmasında ve savunulmasında önemli köşe taşlarından birisi olan örgütlenme özgürlüğü, ILO’nun üç taraflı yapısında önemli bir yeri kaplamaktadır. Örgütlenme özgürlüğü, başlangıçtan beri ILO'nun temel prensiplerinden birisi olarak kabul edilmiştir. Sendika hakkı ile toplu pazarlık ve grev hakkı arasında yaşamsal bir bağ vardır ${ }^{12}$. Grev ve toplu pazarlıksız sendika hakkı üyelerin ekonomik ve sosyal hak ve çıkarlarını koruyup geliştirme amacını güden sendikaların varlık sebeplerinin sorgulanmasına neden olabilecektir. ILO denetim organları vermiş oldukları kararlarında hiçbir ayrım gözetmeksizin grev hakkının tüm çalışanlara tanınmış olduğunu, sendika hakkının kişiler yönünden kapsamı konusunda hiçbir sınırlama yapılmayacağını kamu görevlilerinin de bu haktan yararlanması gerektiğini açıkça ortaya koymaktadır ${ }^{13}$. Grevi de içeren toplu eylem hakkı, uluslararası insan hakları hukukunda önemli bir yere sahiptir. Ancak ILO’nun 2012 yılındaki konferansında İşveren grubunun, grev hakkı ile ilgili yapmış olduğu olduğu müdahale ve yorum neticesinde ILO'nun tarih boyunca yüklenmiş olduğu bu misyonun etkinliğine ilişkin soru işaretleri gündeme gelmiştir.

Grev hakkının, uluslararası niteliği kazanmasında önemli katkısı olan ILO’nun grev hakkına bakışı ile ilgili süreç dinamik bir yapı sergiler.

Birleşmiş Milletler ve Uluslararası Çalışma Örgütü uluslararası çalışma hukukunda grevi de içeren toplu eylem kavramının gelişiminde temel kaynak olma rolünü üstlenmişlerdir. ILO’nun kurulduğu günden bu güne özel bir önem verdiği örgütlenme özgürlüğü ve onun bir parçası olan sendika özgürlüğü ilgili önemli bir içtihat havuzu oluşmuştur. Doğrudan grevi de içeren toplu eylem hakkı ile ilgili sözleşme ya da tavsiye kararları olmasa da ILO denetim organları bu konu ile ilgili önemli bir işlev

10 Lee Swepston, "Human Rights Law and Freedom Of Association: Development Through ILO Supervision”, International Labour Review, 137/2, (1998), s.176.

11 Mesut Gülmez, Sendikal Haklarda Uluslararası Hukuka ve Avrupa Birliğine Uyum Sorunu Ankara: Belediye İş Yayınlar1, 2005, s.138.

12 Mesut Gülmez, "Sendika Hakkı, Toplu Sözleşme ve Grevi de İçeren Toplu Eylem Haklarını Kapsar mı?", Çalışma ve Toplum Dergisi, 18/3 (2008), s.139.

13 ILO, Governing Body Report, Digest of Decisions and Principles of the Freedom of Association Committee. 2006, s. 218. 
görmüşlerdir. Uluslararası çalışma hukukunun gelişiminde önemli bir yeri olan ILO bu konuda öncül bir görevi var olduğu söylenebilir. ILO’nun sendika özgürlüğü ile ilgili onaylamış olduğu ve sendikal hak ve özgürlükler ile ilgili önemli bir içtihatın oluşmasına kaynaklık eden iki önemli sözleşmesi bulunmaktadır. Bu sözleşmeler 87 Sayılı Sendika Hakkı ve Sendika Özgürlüğünün Korunması Sözleşmesi ve bir diğeri ise 98 Sayılı Örgütlenme ve Toplu Pazarlık Hakkı Sözleşmesidir. Bu iki sözleşme de ILO’nun temel sözleşmeleri arasında yer almaktadır. 9 Temmuz 1948 tarihinde kabul edilen ve 153 ülke tarafından onaylanan 87 sayılı ILO sözleşmesi sendika özgürlüğünü en kapsamlı şekilde ele alan uluslararası belgelerin başında gelmektedir.

87 ve 98 sayılı sözleşmelerin kabul edildiği yıllarda ILO, greve yönelik sınırlamalar ve sendikalar üzerindeki baskı ile ilgili olarak şikâyetlere hızla cevap verebilecek mekanizmalara ihtiyaç duymuştur. ILO Yönetim Kurulu, ortaya çıan birçok şikâyetin mevcut denetim mekanizmaları ile uyumlu olamayacağının farkındaydı. $\mathrm{Bu}$ ihtiyaç doğrultusunda 1951 yllında Sendika Özgürlüğü Komitesi (SÖK) kurulmuştur. Sendika Özgürlüğü Komitesi'nin kurulması sendikal özgürlüğüne, uluslararası kurallarla işlerlik kazandırılması için atılan önemli ve olumlu adımlardan birisi olarak değerlendirilmektedir ${ }^{14}$. ILO’nun sendika özgürlüğü ile ilgili sözleşmelerinin metinlerinde grev hakkı kavramı yer almamış olsa da Sendika Özgürlüğü Komitesi ve Uzmanlar Komitesi’nin kısacası ILO’nun denetim organlarının vermiş olduğu kararlarda sendikal hakların grevi de içerecek şekilde bir bütün olduğu vurgusu yapılmıştır. SÖK vermiş olduğu kararlarında, grev hakkının 87 Sayılı Sendika Özgürlüğü ve Örgütlenme Hakkının Korunması ILO sözleşmesinde garanti altına alınan örgütlenme özgürlüğünün doğal bir sonucu olduğunu belirtmektedir ${ }^{15}$. Sendika Özgürlüğü Komitesi 1952 yılında Jamaika ile ilgili vermiş olduğu kararında ilk kez grev hakkını, sendikal hakların bir parçası olarak değerlendirilmiştir. SÖK,bu olayda vermiş olduğu kararında grev hakkının ve sendikal eylem özgürlüğünün sendikal hakların temel aktörlerinden birisi olduğunu belirtmiştir. Hükumet tarafından sendikal eylemlerin yasaya uygunluğu için alınan önlemlerin sendikal faaliyetlerin önlenmesi ile sonuçlanmaması gerektiği vurgusu yapılmıştır. Sendika Özgürlüğü Komitesi vermiş olduğu bu karar doğrultusunda grev hakkı üzerinde sınırlama olup olmayacağı konusunu da ele almıştır. Örgütlenme özgürlüğünün garanti altına alan 87 sayılı sözleşmenin kabulünden 4 yıl sonra grev hakkının varlığını böylece açıkça kabul edilmiştir. Ancak grev hakkının sınırsız bir hak olmadığı da belirtilmiştir ${ }^{16}$. Uzmanlar Komitesi ise 87 sayılı ILO Sözleşmesi onaylandıktan 10 yıl sonra grev hakkı ile ilgili kararını vermiştir.

Uzmanlar Komitesi bu kararında grev hakkı ile örgütlenme hakkı arasında sıkı bir ilişki olduğunu vurgulamışıır ${ }^{17}$. Bunun yanı sıra grev hakkı, çalışanların ve örgütlerinin temel haklarından birisidir ${ }^{18}$. Uluslararası çalışma hukukunun temel varsayımları içinde sendikal hakların bütünselliği yer almaktadır. Sendika özgürlüğü,

14 Mesut Gülmez, "Sendika Özgürlüğüne Saldırı Yakınmaları", Amme İdaresi Dergisi, 18/4 (1988), s.108. 15 ILO, Governing Body Report, Digest of Decisions and Principles, s.218.

16 ILO, Sixth Report of the International Labour Organisation to the United Nations, 1952, s.210.

17 ILO, Report of the Committee of Experts on the Application of Conventions and Recommaditions, ILC $43^{\text {rd }}$ Session, Part: 1, Report: 3, 1959, s.129.

18 ILO, $311^{\text {th }}$ Reports of Freedom of Association Committee, Vol: 81, Seri: B, No: 3, 1998, s.127. 
toplu eylem ve grev hakkı ile bölünmez bir bütünü meydana getirmektedir. İşveren grubunun ise ILO denetim organlarının grev hakkı ile ilgili verdikleri kararlarla ilgili eleştiri ILO denetim mekanizmasının etkinliğinin sorgulanmasına sebep olmuştur.

\section{Uluslararası Çalışma Örgütü’nde Grev Hakkı ile İlgili Kriz}

Uluslararası Çalışma Örgütü’nde krizine yol açan şeyin ne olduğunun ele alınmak istenilmesi bu çalışmanın odak noktasını oluşturmaktadır. Uluslararası Çalışma Örgütü’nün 2012 yılında yapmış olduğu 101. Konferansı'na uluslararası çalışma standartları bağlamında, grev hakkının var olup olmadığı sorunu hakkındaki uyuşmazlıklar damgasını vurmuştur. Bu Konferansta ILO’daki denetim sisteminin etkinliği işveren grubu tarafından eleştirilmiştir. 2012 yllında düzenlenen Uluslararası Çalışma Konferansı̉nda uluslararası çalışma standartlarını ve sosyal standartları ciddi şekilde ihlal etmekle suçlanan ülkelerin bir listesinin yapılıp onaylanması işverenler tarafından engellenmiştir. ILO sözleşmelerini ciddi bir şekilde ihlal ettiği ifade edilen 25 ülkenin yer aldığı listenin tartışlması işveren grubu tarafından engellenmiştiir ${ }^{19}$.

Grev hakkı ile ilgili ayrıntılı ve kapsamlı bir içtihat meydana getiren Sendika Özgürlügü Komitesi’nin tarihi yorumlarına işverenler tarafından yapılan eleştiri, aynı zamanda ILO’nun denetim sisteminin sorgulanmasına sebep olmuştur. Aplikasyon Komitesi ve ILO Konferansı ilk kez, ILO temel fonksiyonlarını yerine getirmede acziyete düşmüş olduğu belirtilmektedir ${ }^{20}$.

2012 yılında işveren grubunun grev hakkı ile ilgili konularının tartışılmasını engelleyişi aslında doğrudan ILO ve onun var olma nedenini riske atan bir krizdir. İşverenlerin 2012 yılındaki böylesi bir meydan okuyuşu ILO denetim sisteminin fonksiyonunun etkinliği için soru işaretlerinin oluşmasına sebep olmuş olabilir. ILO’nun denetim mekanizması ILO’nun güvenilirliği ve etkinliği bakımından da kritik noktalardan birisidir.

2012 yllındaki Konferans gündemine işveren grubunun bu müdahalesinin benzeri 1994 yllında da gerçekleşmiş olduğu belirtilmektedir. Uzmanlar Komitesi’nin 87 ve 98 sayılı sözleşmelerinin toplu incelemesi sırasında grev hakkının tartışılması sırasinda işveren grubu eleştiride bulunmuştur. Ancak bu durum ILO denetim mekanizmasının etkinliğinin sorgulanmasına yol açan bir krize dönüşmemiştir ${ }^{21}$.

Çalışanların hak ihlalleri ile ilgili kötü örneklerinin bazılarının tartışılması 2012 yılındaki ILO Konferansı̉nda işveren grubunca engellemiştir. 1926 yllından günümüze kadar Cenevre'de ILO Uzmanlar Komitesi'nin yıllık raporlarında yer alan en ciddi örnekler tartışılmaktadır. Ancak, 2012 yılında işveren grubu grev hakkı konusunu tartışmayı kabul etmemiştir. 2012 yılındaki ILO Konferansı'nda işveren grubu Konferansın olağan sürecine müdahale ederek grev hakkı ile ilgili ihlallerin değerlendirilmesini engellemiştir. İşveren grubunun 1989 yılından beri grev hakkına olan karşıtlıkları bağlamındaki tepkileri bilinmektedir. Bu durumda aslında işverenlerin

19 Claduia Hoffman, Grev Hakkı ve Uluslararası Çalışma Örgütü, İstanbul: Frederich Ebert Vakfı, 2014, s.1. 20 Francis Maupain, “The ILO Regular Supervisory System: A Model in Crisis?”, International Organizations Law Review, 10/1 (2013), s.117.

21 Gülmez, Sendikal Hakların Ulusal Üstü, s.382. 
ne Sendika Özgürlüğü Komitesi ve Uzmanlar Komitesi’nin verdiği kararları desteklediği ne de grev hakkına destek vermiş olduğu söylenebilir ${ }^{22}$.

ILO'daki bu konuyla ilgili uzman değerlendirmelerinden birisinde şöyle bir ifade kullanılmaktadır: "Örgütlenme ve toplu pazarlı̆̆ın temel prensiplerini düzenleyen 87 ve 98 sayılı sözleşmelerde grev hakkından söz edilmediğine dair tartışmada işveren grubu kuşkusuz ki haklıdır" demektedir ${ }^{23}$. Sendika Özgürlüğü ve Örgütlenme Hakkının Korunmasına ilişkin 87 Sayılı ILO Sözleşmesi’nin 3. maddesi "çalışanların kendi örgütlerini kurma, kurallarını, temsilcilerini, yöntemlerini organize etmede, eylemlerini ve programlarını belirlemede serbest olduğunu" ifade etmektedir. Aynı sözleşmenin 10. maddesi, "çalışanların örgütlerini, çalışanların çıkarlarını koruyucu ve geliştirici yapılarından” söz edilmektedir. Bu görüşteki amaç 87 sayılı sözleşmenin 3.1. maddesinin sendikaların eylemlerini örgütlerken aynı zamanda grev, oturma eylemi gibi dışsal eylemlerin pratiklerinde de özerkliği ve örgütlenmeyi de kapsadığı anlaşılabilir. 87 sayılı Sözleşmenin 3.1. maddesi çalışanların eylemlerini ve yönetimlerini belirleme hakkına sahip olduklarını belirtir. Örgütlenme kavramı sadece bir takım kuralları düzenlemeyi değil aynı zamanda şekillendirmeyi de içermektedir. Sendikaların eylemlerini şekillendirmede ve çalışanların çıkarlarını geliştirmede meydana gelen bir endüstriyel uyuşmazlığın çözümünde greve başvurma "ultimate ratio" kısacası en son çare olarak düşünülmektedir. Bu görüş aynı zamanda Sendika Özgürlüğü Komitesi ve Uzmanlar Komitesi tarafından da kabul edilen bir görüştür. Sendika Özgürlüğü ve Uzmanlar Komitesi altmış yıldan fazla bir süredir verdikleri kararlarında grev hakkının sendika özgürlüğünün ayrılmaz bir parçası ve merkezi bir bileşeni olarak görmektedirler ${ }^{24}$.

Uzmanlar Komitesi ise koşulsuz bir grev hakkından söz etmemektedir. Uzmanlar Komitesi grev hakkı ile ilgili bazı sınırlamalar olabileceğini belirtilmektedir. Bu s1nırlamalar genellikle sempati grevi, siyasi grev ve kamu kesimindeki bazı grevlerdeki kısıtlamalar gibi grevin şekliyle ilgilidir. Uzmanlar Komitesi grev hakkının koşulsuz ve sınırsız bir hak olarak görmemektedir. Grev hakkının bazı sınırlarının olması olağandır, ancak bu sınırlama çalışan kategorisi içinde çok geniş bir biçimde ele alınamaz. Tümüyle grev hakkının yasaklayan ya da büyük ölçüde kısıtlayan bir yaklaşım ILO'nun sendikal haklarla ilgili sözleşmelerinin felsefesine de uyumlu olmayacaktır. Çünkü bu sözleşmelerin mantığında yer alan en önemli şey "her ne olursa olsun ayrımcılık yapılmamasıdır." Uzmanlar Komitesi grev hakkı ile ilgili benimsediği görüşünü 1959 yılından beri sürdürmektedir. Grev hakkı ile ilgili kısıtlama bakımından kamu görevlileri için temel hizmetlerde çalışan kamu görevlileri ve devlet adına otorite kullanan kamu görevlileri için kısıtlamalardan söz edilebilir, ama bu kısıtlama daha önce de belirtildiği gibi çok geniş ölçüde düşünülmemelidir. Uzmanlar Komitesi’nin sahip olduğu yaklaşımın temelinde aslında işveren ve çalışan grubu arasında bir dengeyi ve ahengi sağlamak vardır. Bunu gerçekleştirme noktasında uluslararası standartların rehberlik ettiği dengeli bir yaklaşım benimsenmektedir. Grev hakkının

22 Claire La Hovary, "Showdown at The ILO? A Historical Perspective on Employer's Group's 2012 Challenge to the Right to Strike", Industrial Law Journal, 42/4 (2013), s.339.

23 Claudia Hoffman ve Norbert Schuster, "Some Reflections on the Right to Strike and Its Treatment on the ILO", ILO, Working Paper No: 28, 2014, s.7. 
metninde geçmediği 87 sayılı sözleşmeyi onaylayan birçok ülke kendi ulusal mevzuatlarında grev hakkını tanımışıı ${ }^{25}$. Böylelikle grev hakkının işveren grubunun 2012 yılında ILO’nun 101. Konferansı’nda öne sürdügü gibi grev hakkının sözleşme metninde yer almaması, bu hakkın inkâr edileceği anlamına gelmemektedir.

Uzmanlar Komitesi değerlendirmeleri ve tecrübeleri işveren tarafını da göz önüne aldığını göstermektedir ve bu şekilde çalışanların çıkarlarının korunması ve geliştirilmesinde her iki tarafı da uyumlu bir noktaya getirmeyi istemekte ve böylece optimum yardımı sağlama hedeflenmektedir. Amaçlanan hedef, işverenler ve çalışanlar arasında bir ahenk sağlayabilmektir. Bu ahenk anayasal zeminde " uygulamadaki benzeşimin" koruyucusu olacaktır. Bu yüzden Komite, uluslararası standartların rehberliğinde dengeli bir yaklaşımı tercih etmektedir. İnsan hakları kategorisinde yer alan böylesi bir hakkın ulusal ve uluslararası düzenlemelerde "dilenilmesi " için açı bir kapı bırakılmaması gerektiği ifade edilmektedir. Bu yüzden Uzmanlar Komitesi ve Sendika Özgürlüğü Komitesi uluslararası standartların eşliğinde dengeli bir yaklaşımı tercih etmektedir ${ }^{26}$.

Bununla birlikte diğer önemli bir nokta da şudur ki; grev hakkının yıllardır vurgulayan Uzmanlar Komitesi ve Sendika Özgürlüğü Komitesi, uzun yıllardır dengeli bir yaklaşım sergileyebilmek için işveren temsilcileri ile mücadele etmektedirler. 1994 yılına kadar bu konu ile ilgili bir direnç görülmemiştir. Yıllardır grev hakkı ile ilgili çok şiddetli tartışmaya girmeyen işveren tarafının yıllar sonra böylesi şiddetli bir tepki vermesi şaşırtıcı olduğu düşünülmektedir. Bunun yanı sıra Sendika Özgürlüğü Komitesi’nin çalışmaya başladığı 1952 yılından itibaren yaklaşık kırk yıllık süreçte grev hakkıyla ile ilgili geliştirdiği içtihatlarda işveren grubu tarafından bir meydan okuma söz konusu olmadığ da ifade edilmektedir ${ }^{27}$. Sendika Özgürlügü Komitesi grev hakkını doğrulayan ve bu uygulamayı düzenleyen kararlar almıştır. Grev hakkı ile ilgili Uzmanlar Komitesỉnin ise yapmış olduğu incelemeler Uluslararası Çalışma Konferansı'nda ILO’nun üçlü yapısı tarafından düzenli bir şekilde kabul edilmiştir. Soğuk Savaş่ın sonuna kadar İşveren Grubu’nun, ILO tarafından korunan grev hakkının varlığı ile ilgili bir sorun oluşturmadığ ifade edilmektedir. İşveren Grubu’nun şikâyetleri 1989 ve 1992'de yüzeye çımıştır. 1994 yllında Örgütlenme ve Toplu Pazarlık Özgürlüğü Genel İncelemesi Raporu'nda İşveren Grubu ILO denetim sistemi organları tarafından geliştirilen grev hakkı üzerinde durmuştur. İşveren Grubu, denetim organları tarafından grev hakkının tanımlanmasına değil grev hakkı kapsamının geniş şekilde ele alınmasına ve grev hakkının sınırsız şekilde tanımlandığı vurgusu üzerinde durmuşlardır. Oysa ne Sendika Özgürlüğü Komitesi ne de Uzmanlar Komitesi sınırsız bir grev hakkı tanımlamasına gitmemişlerdir ve hatta zaman içerisinde grev hakkı ile ilgili sınırlamalar getirmişlerdir. Bunun yanı sıra Sendika Özgürlüğü Komitesi’nin incelediği vakalar ile Uzmanlar Komitesi’nin ulaştığı sonuçlar arasında uyumsuzluk ya da dengesizlik olmadığ 1 belirtilmektedir. 2012 yılına

25 Claudia Hoffman ve Norbert Schuster, "It ain't Cover Till It's Over: The Right to Strike and the Mandate of the ILO Committe of Experts Revisited”, ILO, Working Paper No: 40, 2016, s.23.

26 Hoffman ve Schuster, "Some Reflections on The Right to Strike", s.4.

27 Hovary, "Showdown at The ILO?", s.338. 
kadar İşveren Grubu, uluslararası grev hakkının var olmadığı tartışmasını gündeme getirmemiştir ${ }^{28}$.

Grev hakkının uluslararası alanda tanınması ile ilgili işveren grubunun ILO‘da krize sebep olan bazı iddiaları vardır. İşveren grubu, Uzmanlar Komitesi'nin grev hakkı ile ilgili karar verme mekanizması olmadığını belirtmiştir. Bunun üzerine ILO Yönetim Kurulu, Uzmanlar Komitesi’nin adeta bir çeşit mahkeme gibi çalışmadığını, Komite’nin üye ülkelerin, sözleşmeyi yorumlamaları konusunda sınırlı bir görevi olduğunu belirtmiştir. Bu durumda grev hakkına uluslararası temel kazandıran ILO'nun organları arasında bir çelişki yaşadığını söylemek mümkündür ${ }^{29}$.

İşveren grubu, grev hakkıyla ilgili kural ve uygulamaları belirleme yetkisinin hükümetlere düştüğünü savunmuştur. İşveren grubuna göre grev hakkının 87 sayılı sözleşme bağlamında, bu sözleşmenin kapsamında olduğunun düşünülmesi doğru bir yaklaşım değildir. İşveren grubuna göre Uzmanlar Komitesi’nin, grev hakkının "uluslararası bir insan hakkı" olduğu yaklaşımı, ulusal hükumetlerin grev hakkını tanımlama yetkisini kısıtlayacaktır ${ }^{30}$. Danimarka İşveren Temsilcisi, grevin ulusal yasa ile bağlantılı olduğunu, uluslararası hukuk ile bağlantılı olmadığını belirtmiştir $^{31}$. İşveren grubu 87 sayılı Sözleşmede grev hakkının yer almadığını ve Uzmanlar Komitesi’nin de sözleşmelerin yorumlanması gibi bir yetkisinin bulunmadığını belirtmektedir $^{32}$. İşveren grubuna göre Uzmanlar Komitesi’nin yetkisi 87 Sayılı sözleşmenin uygulanmasını yorumlamaktır, Komite'nin görevi 87 Sayılı Sözleşme’nin grev hakkını kapsadığı şeklinde bir yoruma varmak değildir ${ }^{33}$. İşveren grubuna göre sözleşmenin yorumu, ILO Anayasası'nın 37. maddesi gereğince Uluslararası Adalet Divanı (International Court of Justice)'na aittir. ILO Anayasasının 37 maddesi ise şöyledir: "Bu Anayasanın ve bu Anayasa gereğince üyelerce daha sonra onaylanan sözleşmelerin yorumlanmasına ait her türlü sorun veya güçlükler Uluslararası Adalet Divanının değerlendirmesine sunulacaktır.” İşveren grubuna göre 87 Sayılı Sözleşmede de örgütlenme özgürlügünden söz edilmektedir ve örgütlenme özgürlügü ile ilgili olarak 87 sayılı Sözleşmenin farklı bir denetim prosedürü vardır ve bu denetim de Sendika Özgürlüğü Komitesi aracılığı ile yapılmaktadır. Bununla birlikte Uzmanlar Komitesi uzun yıllardır grev hakkı ile ilgili yorumlarında Sendika Özgürlüğü Komitesi'nin vakalarını kullanmakta ve böylece aslında Sendika Özgürlügü Komitesi yorumlarını kullanarak sonuca varmakta olduğu işveren grubu tarafından belirtilmiştir. İşveren grubu bununla birlikte bu karışıklığın önemli olduğunu ve bu durumun denetim sisteminin yarattığ 1 örtük bir durum olduğunu belirtmiştir ${ }^{34}$.

28 Tonia Novitz, "Connecting Freedom of Association and Right to Strike: European Dialogue with the ILO and Its Potential Impact”, Canadian Labour and Employment Law Journal, 15/3 (2010), s.476.

29 John Kloosterman, Shareholder, Littler, "The Right to Strike: The ILO’s Freedom of Association Convention", Ius Laboris Global Human Resources Lawyers Bulletin, 2013, s.2.

30 Gülmez, Sendikal Hakların Ulusal Üstü, s.388.

31 ILO Report of the Committee on the Application of Standards: Submission, Discussion, and Approval. Record of Proceedings, No 27, International Labour Conference 101st Session, 2012, s.23.

32 ILO, 101st Session, s.22.

33 ILO, 101st Session, s.33.

34 ILO, 101st Session, s.34. 
İşveren grubuna göre, Uzmanlar Komitesi’nin ILO içinde hukuki yorum yapma yetkisi bulunmamasına rağmen Uzmanlar Komitesi’nin grev hakkı ile ilgili olarak yaptığı yorumlar hukuki yorumlardır. Bununla birlikte "Uzmanlar Komitesinin ILO denetim mekanizmasında tanımlayıcı bir rolü yoktur ve Komite'nin emek standartlarını denetleyemeyeceği” belirtilmiştir. İşveren grubunun iddiası ise Uzmanlar Komitesi’nin ve hatta ILO’nun üçlü yapısının çalışma standartlarını yönetemeyeceğidir. Hukuki bir niteliği olmayan Uzmanlar Komitesi'nin 87 Sayılı Sözleşme' de grev hakkının var olduğu şeklindeki yorumu ne kadar yersiz ise Sendika Özgürlüğü Komitesỉnin de grev hakkı ile ilgili kararlarının o kadar yersiz olduğu vurgulanmıştır. İşveren grubuna göre 87 sayılı ILO sözleşmesi grev hakkı konusunda sessizdir ve bu yüzden Uzmanlar Komitesỉnin hakkında açıklama yapabileceği bir konu değildir. İşveren Grubuna göre ILO’nun 87 sayllı sözleşmesinin metninde grevi refere eden herhangi bir şey olmadığı için, uluslararası alanda kabul edilen kuralların yorumu ILO’nun 87 sayılı sözleşmesini grev hakkı olmaksızın yorumlamayı gerektirmektedir ${ }^{35}$. İşveren grubunun bu sert yorumu ILO denetim organlarının varlığ ve işlevinin sorgulanmasına sebep olmaktadır. İşveren grubu tarafından yapılan bu sert eleştirilerin ILO’nun uluslararası alandaki amacına uygun olmadığ ifade edilebilir. İşveren grubunun eleştirilerinin temelinde işveren grubunun sendika karşıtllğ̆ ya da yönetim anlayışını paylaşmak istemeyişinin de yer alabileceği düşünülebilir. İşveren grubu, Uzmanlar Komitesi'nin adeta bir hukuk uygulayıcısı gibi grev hakkı ile ilgili karar veremeyeceği vurgusunu yapmaktadır ${ }^{36}$.

Çalı̧san temsilcisi ise Uzmanlar Komitesi'nin ILO Sözleşmelerini yorumlayıcı fonksiyonunun göz ardı edilmesinin çok sakıncalı olduğunu belirtmiştir. Temsilci, Uzmanlar Komitesi'nin tarafsızlık, objektiflik ve bağımsızlık ilkelerini takip eden bir teknik organ olduğunu belirtmiştir ve Komite sözleşmeleri tanımlayıcı bir şekilde yorumlamamaktadır ${ }^{37}$. Grev hakkının olmayışı, çalışanların toplu pazarlığın bir parçası olmasını engellemektedir. Örgütlenme özgürlüğünün ayrılmaz bir parçası olan grev hakkının sorgulanması, pratikte diğer hak ve özgürlükleri de anlamsızlaştıracaktır. Temel hakların, denetim mekanizması aracılığıyla ILO Sözleşmeleri’nin yorumlanması sosyal haklar ile sivil özgürlükler arasındaki devamlılığın sürmesini sağlamaktadır ${ }^{38}$. Bununla birlikte Çalışan Grubu üyesi, şu değerlendirmelerde bulunmuştur:

ILO’nun onaylamış olduğu temel sözleşmeler insan hakları ile ilgilidir ve bu sözleşmeler demokrasinin gelişmesi için temel aktörlerden birisidir. 87 ve 98 Sayılı Sözleşmeler de bu temel sözleşmeler içinde yer almaktadır. Ve grev hakkının 87 Sayılı Sözleşme 'den türetildiğini doğrulamak çok önemlidir ve bu hak örgütlenme özgürlüğünün doğal sonucudur ${ }^{39}$.

Kanada Hükumet Temsilcisi, Robinson "grev hakkı ile ilgili ihlallerin bu yılki Konferans'ta ele alınmamasının sonucunda ortaya çıkan mağdurların, savunmasız durum-

35 ILO, 101st Session, s. 35. 36 ILO, 101st Session, s.22. 37 ILO, 101st Session, s.23. 38 ILO, 101st Session, s.23. 39 ILO, 101st Session, s.27. 
daki tüm dünyadaki çalışanlar" olduğunu belirtmiştii ${ }^{40}$. Çalışan grubu ise işveren grubunun grev hakkı ile ilgili konuların görüşülmek istemeyişinin ILO’nun üçlü yapısını ve denetim etkinliğini tehlikeye düşüreceğini belirtmiştir ${ }^{41}$.

Haziran 2012'de İşveren Grubu, yaptığı müdahale ile yıllardır ILO’nun tüm bileşenleri tarafından kabul edilmiş olan grev hakkına meydan okumuştur. Bu meydan okuma ILO Komitelerinin yetki alanlarına da müdahaleyi beraberinde getirerek, ILO’nun diğer sözleşmelerinin de gelecekte yorumlanmasında müdahaleyi açık hale getirebilecektir.

İşveren grubu bu müdahaleye devam ederse ILO’nun önünde iki seçenek bulunmaktadır. İlki ILO Yönetim Kurulu Uluslararası Adalet Divanı’ndan istişari bir karar verilmesini ve uyuşmazlığa son verilmesini isteyebilecektir. Bir diğeri ise uyuşmazlık konusu sorunla ilgili hızlı bir şekilde karar verilmesinin sağlanması için bağımsız bir mahkemenin kurulmasina karar verilebilir ${ }^{42}$.

İşçi temsilcileri ve bazı devlet temsilcileri işveren grubunun böylesi bir meydan okuyuşu karşısında keskin bir anlaşmazlık içinde olduklarını ifade etmişlerdir. İşveren grubu ise daha sonra ILO’nun tüm denetim sistemlerinin kriz içinde olduğunu ve bu durumun ILO’nun işleyişinde bir değişimi gerektirdiğini belirtmişlerdir ${ }^{43}$.

İşveren grubunun bu sert tavrının ILO dışında meydana gelen içtihadın motive ettiği belirtilmektedir. Ulusal ve yerel mahkemeler, kendi kanunları ve aktörleri gereğince ILO’nun denetim organlarındaki örgütlenme özgürlüğü ile ilgili metinleri daha hızlı bir biçimde uygulamaya çalışmaktadırlar.

2012'de gerçekleşen ILO Konferansi’nda İşveren grubu Sendika Özgürlügü Komitesi’nin 87 sayılı sözleşmeyi grev hakkı bağlamında geniş ve ayrıntılı bir şekilde yorumladığını ifade ederek Uzmanlar Komitesi’nin incelenmesini önerdiği konulara bloke koyması ile ILO denetim sisteminin etkinliğinin sorgulanmasına yol açmıştır. İlk kez Aplikasyon Komitesi ve ILO Konferansı ILO’nun temel fonksiyonlarını yerine getirme konusunda kendilerini aciz görmüşlerdir.

İşverenlerin grev hakkı ile ilgili görüş ve gözlemlerinden yola çıkarak Uzmanlar Komisyonu yetki gaspı ile suçlanmıştır. Komite siyasi bir amaç taşıyan bir organ olmadığg için farklı bir konumdadır. Uzmanlar Komitesi’nin görüş ve yorumlarının bağlayıcı bir niteliği yoktur. Uzmanlar Komitesi’ni baskı altına alarak frenlemek zaten yaptırım gücü son derece sınırlı olan ILO denetim mekanizmasına, üye devletlerin asgari normlara uyma iradesini zayıflatabileceği belirtilmektedir. Bu durum ILO'nun sosyal ve sendikal haklar alanında yıllar boyunca elde etmiş olduğu saygınlığa gölge düşürecektir ${ }^{44}$.

40 ILO, 101st Session, s.11.

41 ILO, 101st Session, s.6-7.

42 Hovary, "Showdown at The ILO?", s.367.

43 ILO Governing Body Report, Matters Arising Out of Work of the International Labor Conference, International Labour Conference, 317th Session. 2013, s.14-15.

44 Gülmez, Sendikal Hakların Ulusal Üstü, s.588. 
2012 yılındaki Uluslararası Çalışma Konferansı'nı takiben, ILO bu zor durumdan kurtulmak için resmi görüşme takviminin yanı sıra 2013 yılında gayri resmi bir görüşme gündemi de oluşturmuştur. 2012 Kasım ve 2013 Şubat ayında yeni bir gayri resmi görüşme düzenlenmiştir.

2012 Kasım ayında yapılan ILO’nun 316. Toplantısı'nda gayrı resmi üç taraflı bir toplantı yapılmıştır. İşveren Grubu tavrında bir değişiklik sergilemeden, grev hakkı ile ilgili olarak Uzmanlar Komitesi’nin neden 87 Sayılı Sözleşme ile ilgili yorum yapma yetkisi olmayan bir organ olduğunun gerekçelerini sıralamıştır. İşveren Grubu'na göre Uzmanlar Komitesi teknik bir organdır ve bu organın hukuki bir işlevi yoktur.

Uzmanlar Komitesi’nin sözleşmelerin yorumu ile ilgili fonksiyonu ilk yıllarda dahi tartışılıp reddedilmiştir. İşveren temsilcisi John Kloosterman, böyle bir yetkisi bulunmayan Uzmanlar Komitesi’nin yıllar içinde sözleşmelerin yorumlanması ile ilgili işlevini geliştirdiğini belirtmiştir. ILO Anayasası'nda açık bir referans olmamasına rağmen Uzmanlar Komitesi bu yetkiyi kendi kendisine vermiştir ${ }^{45}$.

2013 yılında yapılan toplantıda işveren grubu yeniden ağır eleştirilerde bulunmuşlardır. İşveren grubuna göre grev hakkı 87 Sayılı Sözleşme’de düzenlenmemiştir. Bunun yanı sıra İşveren Grubu 87 Sayılı Sözleşme hazırlanırken ILO’nun yetkili organlarının sözleşmede grev hakkının içerilmesini kabul etmediklerini belirtmiştir. 87 Sayılı Sözleşme’nin okunmasından grev hakkı çıkarılamayacağı vurgulanmıştır. İşveren grubuna göre uluslararası bir belgede açıklanmayan bir hakkın yorumlanmasında ulusal uygulamalara gönderme yapılması, 87 sayılı Sözleşme’nin grev hakkının kaynağı olduğunu kanıtlama olanağı vermemektedir ${ }^{46} .2013$ yılında İşveren Grubu ILO’yu krize sürükleyen taleplerinden vazgeçmemişlerdir.

İsveç Hükumeti, işveren grubu ve işçi grubu arasındaki iki taraflı görüşmeleri sağlamak ve eğer üçlü danışmaya başvurmadan önce sosyal taraflar arasında bir anlaşmaya varılıp varılmayacağını görmek için olanak sağlamıştır. Bu toplantılar Mayıs, Haziran ve Eylül 2013'te düzenlenmiş. Ancak, bu konuların çözümünde başarısız olunmuştur.

2013 yılındaki Uluslararası Çalışma Konferansı’nda taraflar Sendika Özgürlüğü Komitesi’nce tartışılan 25 maddelik bir liste üzerinde anlaşabilmişler; ancak, İşveren Grubu örgütlenme özgürlüğ̈̈ ile ilgili dosyaların sonuç cümlesi olarak " 87 sayılı ILO sözleşmesinde grev hakkının tanınmış olduğu fikrine işveren grubunun katılmadı̆̆ını ve komitenin bu dosyalarda grev hakkına değinmediği” şeklinde bir ifadenin yer almasında israr etmişlerdir ve raporda bu ifade yer almıştır ${ }^{47}$. Ancak bu durumda işveren grubunu tatmin etmek için yeterli olmamıştır ve İşveren grubuna Uzmanlar Komitesinin sınırı aşmış olduğunu belirtmiştir.

45 ILO, Minutes of the 316th Session of the Governing Body of the International Labour Office, Geneva, $316^{\text {th }}$ Sesion, 2012, s.22.

46 Gülmez, Sendikal Hakların Ulusal Üstü, s.392.

47 Hoffman ve Schuster, "It ain’t Cover Till It’s Over”, s.6. 
2014 Mart ayında, ILO Genel Konferansı'nda ortaya çıkan tartışmaların üstesinden gelebilmek için ILO Yönetim Kurulu çeşitli çözüm arayışı içine girmiştir. Bu amaçla Kasım 2014'te toplantı için ILO Genel Direktörünün bir doküman hazırlamas1 istenilmiştir. Böyle bir raporun ILO Anayasası 37/1 ve 37/2 doğrultusunda ILO sözleşmelerine müdahale ve uyuşmazlık durumunda izlenebilecek yöntem ve kapsam konusunda düzenleme içermesi istenilmiştir ${ }^{48}$. Grev hakkı ile ilgili sorunda ILO Anayasası'nın 37. Maddesine göre yargısal mekanizmaya başvurulma yolu tercih edilmemiştir. ILO Anayasası'nın 37. maddesi şöyledir:

1. Bu Anayasanın ve bu Anayasa gereğince üyelerce daha sonra onaylanan sözleşmelerin yorumlanmasına ait her türlü sorun veya güçlükler Uluslararası Adalet Divanının değerlendirmesine sunulacaktır.

2. Bu maddenin 1 inci fıkrasındaki hükümler dikkate alınmaksızın, Yönetim Kurulu bir sözleşmenin yorumlanmasına ait olup, Kurul tarafından veya anılan sözleşme gereğince mahkemeye gönderilecek her sorun veya güçlüğün çabuk çözümlenmesi amacıyla bir mahkeme oluşturulması hakkında birtakım usuller saptar ve bunu konferansın onayına sunabilir. Uluslararası Adalet Divanının bütün kararları veya danışmaya dayalı görüşleri bu fıkra gereğince oluşturulan her mahkemeyi bağlayacaktır. Böyle bir mahkeme tarafından verilen her hüküm, Örgüt üyelerine gönderilecek ve onların görüşleri Konferansa sunulacaktır. ${ }^{49}$

2014 ILO Konferansında işveren grubu Uzmanlar Komitesinin “ulusların farklı sosyo ekonomik ve kültürel yapılarının yanı sıra hukuk sistemlerinin de farklılı̆̆ının bilincinde olmasına rağmen üye devletlerin, sözleşmenin uygulanması ile ilgili hukuki ve pratikteki durumları ile ilgili tarafsı ve teknik denetimi nasıl gerçekleştirdikleri” eleştirilmektedir. 2015 yılında ILO'da 87 Sayılı Sözleşme ve grev hakkının değerlendirilmesi ile ilgili resmi bir oturum yapılmıştır. Bu oturumda çalışan grubu, grev hakkı ile ilgili görüşlerinin değişmediğini belirtmiştir. Çalışan grubuna göre grev hakkı en temel haklardan birisi ve demokrasinin oluşması için çok önemli bir haktır ${ }^{50}$. Hükumet grubu ise grev hakkının ILO'nun temel ilkelerinden birisi olan sendika özgürlüğü ile bağlantılı bir hak olduğunu vurgulamıştı ${ }^{51} .2015$ yılındaki toplantıda hükumet temsilcilerinin ortak ifadesi, grev hakkının örgütlenme özgürlüğü bağlamında tanınmaması, çalışanların ekonomik ve sosyal hak ve çıkarlarının korunmasının gerçekleşemeyeceğini belirtmişlerdir ${ }^{52}$.

Bu kriz Uluslararası Çalışma Örgütü’nün sınırlarını aşan ve ciddi bir krizdir. Bu, sadece Uluslararası Çalışma Örgütü’nün yıllar süresince oluşturduğu uluslararası hu-

48 International Trade Union Confederation (ITUC), The Right to Strike and the ILO: The Legal Foundations, March 2014, s.10.

49 “Uluslararası Çalışma Örgütü (ILO) Anayasası”, ILO internet sitesi, http://www.ilo.org.

50 ILO, Governing Body Report. Fifth Item on the Agenda: The Standards Initiative 323rd Session, 12-27 March 2015.

51 Jeffrey S. Vogt, “The Right to Strike and the International Labour Organisation (ILO)”, King's Law Journal, 27/1 (2016), s.126.

52 Hoffman ve Schuster, "It ain't Cover Till It’s Over", s.24. 
kuk sisteminin temelinden sarsılması anlamına gelmemektedir. Bu kriz hem Uluslararası Çalışma Örgütü bağlamında grev hakkı ve Uzmanlar Komisyonu’nun ve hatta Sendika Özgürlügü Komitesi’nin yetki sorununun ötesinde, Uluslararası Çalışma Örgütü’nü Uluslararası Çalışma Örgütü yapan kurucu ilkelere saldırı olmasının yanı sıra evrensel ve bölgesel insan hakları kuruluşları çerçevesinde üretilen uluslararası çalışma hukuku normlarına da bir müdahale anlamını taşımaktadır ${ }^{53} .2015$ yılı ILO Konferansı'nın sonunda görüşülecek ihlallerle ilgili listede anlaşılması ILO’da barış ortamının yeniden oluşturulabildiğini göstermektedir, ancak, böyle bir müdahalenin gerçekleşmesi ILO denetim sürecine yeni bir müdahalenin tekrar gerçekleşmeyeceği anlamına gelmeyebilir.

\section{Sonuç}

Grev hakkına ilişkin tartışmalar günümüzde de devam etmektedir. ILO’nun denetim organları toplu pazarlık ve grev hakları ile sendika hakkının birbirinin varlık koşulu olduğunu kabul etmişlerdir. Bu bakımdan sendikal hakların bütünselliği ve bölünmezliğinin uluslararası çalışma hukukunun temel ilkelerinden biri olduğunu söylemek mümkündür.

Uluslararası Çalışma Örgütü’nün 101. Konferansı’na uluslararası çalışma standartları bağlamında, grev hakkının var olup olmadığı sorunu ortaya çımıştır. Bu sorun çerçevesinde taraflar arasında ortaya çıkan uyuşmazlıklar, ILO denetim mekanizmasının etkinliğinin sorgulanmasına neden olmuştur. $\mathrm{Bu}$ durumun, Uluslararası Çalışma Örgütü’nün ötesinde bir kriz olduğu söylenebilir. İșveren grubu tarafından yapılan müdahale sadece Uluslararası Çalışma Örgütü’nün yıllardır oluşturduğu uluslararası hukuk sisteminin temelinden sarsılması anlamına gelmemektedir. Bu kriz Uzmanlar Komitesi’nin ve Sendika Özgürlüğ̈ Komitesi’nin yetki sorununun ötesindedir ve aynı zamanda Uluslararası Çalışma Örgütü'nü Uluslararası Çalışma Örgütü yapan kurucu ilkelere de müdahale olması anlamına gelmektedir. Bunun yanı sıra aynı zamanda uluslararası çalışma hukuku normlarına da kısacası uzun yllların birikimi olan sendikal haklar ortak hukuku sistemine de bir müdahale anlamını taşımaktadır. ILO’nun verdiği kararlarda, denetim mekanizmasının işlerliği bakımından üye ülkeler üzerinde herhangi bir yaptırımı söz konusu olmadığı bilinmektedir. Üye ülkeler üzerinde herhangi bir yaptırımı olmayan ama uluslararası çalışma hukuku bağlamında güçlü bir konumu olan ILO'nun etkinliği de tartışma konusu olmaya başlamıştır. Tartışma noktalarından birisi Uzmanlar Komitesỉnin sözleşme ve tavsiye kararlarını yorumlamaya ilişkin bir zorunluluğu olup olmadığıdır. 1989'dan bu yana grev hakkı ile ilgili olarak itirazlarını gündeme getiren işveren grubunun 2012 yllındaki tepkisinin daha sert olduğu belirtilmektedir. Bu aslında önemli bir ikilemdir. İşveren grubunun, ILO’nun etkinliğini azaltma yönünde bir çabası olup olmadığı da önemli bir sorun noktasıdır. İ̧veren grubuna göre sözleşmede açıkça belirtilmemiş olan grev hakkının var olduğu şeklinde bir yorum yapılamaz.

53 Gülmez, Sendikal Hakların Ulusal Üstü, s.381. 
ILO’nun denetim mekanizmasının etkinliğinin sorgulanmasına yol açan krizin devam etmesi halinde uluslararası çalışma standartlarına olan bağlılığa ilişkin şüphelerin ve tartışmaların doğmasına yol açacağı yönünde endişeler bulunmaktadır.

İşveren grubu, Uzmanlar Komitesi’nin emek standartlarının belirlenmesinde, ILO’nun onayladığı sözleşmelerle ilgili kapsamlı yorumlarda bulunmakta bu durumun da Uzmanlar Komitesi'nin yolunu kaybetmesine yol açtığını iddia etmektedirler. İşverenler, emek standartlarının belirleme işinin ILO’nun bileşenlerine ait olduğu ilkesine işveren grubunun bağlı olduğunu belirtmişlerdir. İşveren grubuna göre bu bağlamda yasa yapma yetkisi olmayan Uzmanlar Komitesi sözleşmelerin yorumlanması konusundaki sınırını aşmaktadır. İşveren grubuna göre Uzmanlar Komitesi’nin grev hakkı ile ilgili görüşlerinin yumuşak bir hukuk içtihadı şeklinde düşünülmesine karşıdır, çünkü işveren grubuna göre 87 sayılı sözleşmenin metninde grev hakkına yer verilmeyişi bilinçli bir tercihtir. Bu bağlamda ILO iş̧̧i işveren ve hükumet arasında bir ahengi sağlamak istemektedir. İşveren grubuna göre ILO’nun grev hakkına metinde yer vermesi ILO’nun objektifliğine gölge düşürebilecektir. Çıkan bu krizde aslında ILO'nun anlamlı faaliyetlerde bulunabilme ve uluslararası çalışma standartlarını ve sosyal standartları denetleme gücü eleştirilmiştir. Böylesi bir krizin tekrar ortaya çıkması halinde ILO'nun bağımsız ve etkin işleyişine gölge düşebilecektir. İşveren tarafının yeni bir müdahalesinin sonuçları ILO denetim mekanizmasının yeniden sorgulanmasına sebep olabilecektir. Uzmanlar Komitesỉnin yetkilerinin azaltılması yönündeki talep eğer uygulamaya geçirilmek istenirse ILO’nun işlevselliği de ciddi bir biçimde zedelenebileceği düşünülebilir. Uzmanlar Komitesi, ILO sözleşmelerini üye ülkelerin ulusal mevzuatlarına nasıl aktardıklarını ve uygulamadaki yansımalarını tarafsız bir şekilde incelemektedir. Uzmanlar Komitesi, sözleşmelerdeki hükümlerin yasal çerçevesini, içeriğini ve önemini üye ülkelerin yasal düzenlemeleri ve uygulamaları bakımından rehber görevi görmektedir. Uzmanlar Komitesỉnin kararlarının hukuki bağlayıcıllğının olmaması işveren müdahalesini kolaylaştırdığı düşünülebilir. Bu kararların üye ülkeleri bağlayıcı hukuki bir nitelik kazanması gelecekte böyle bir krizin yeniden yaşanılması halinde ILO'nun işlevselliği ile ilgili şüphelerin ortaya çıkmasını engelleyebilir.

\section{Kaynakça}

Centel, Tankut. Türkiye’nin Onayladığı ILO Sözleşmeleri. İstanbul: Mess, 1999.

Gemalmaz, Mehmet Semih. Ulusalüstü İnsan Hakları Belgeleri II. Cilt Uluslararası Sistemler. Ankara: Legal, 2010.

Gülmez Mesut. Uluslararası Sosyal Politika. Genişletilmiş 2. Baskı. Ankara: Hatipoğlu Basım ve Yayım, 2011.

Gülmez, Mesut. Sendikal Hakların Ulusal Üstü Kuralları, Oluşumu ve Uygulanması. 2. Baskı. Ankara: Hatiboğlu Basım ve Yayın, 2014.

Gülmez, Mesut. Sendikal Haklarda Uluslararası Hukuka ve Avrupa Birliğine Uyum Sorunu. Ankara: Belediye İş Yayınları, 2005.

Gülmez, Mesut. "Sendika Hakkı, Toplu Sözleşme ve Grevi de İçeren Toplu Eylem Haklarını Kapsar mı?”. Çalışma ve Toplum Dergisi. 18/3 (2008): 137-169. 
Gülmez, Mesut. “Sendika Özgürlüğüne Saldırı Yakınmaları”. Amme İdaresi Dergisi. 18/4 (1988): 105-120.

Hovary, Claire La. "Showdown at The ILO? A Historical Perspective on Employer's Group's 2012 Challenge to the Right to Strike”. Industrial Law Journal. 42/4 (2013): 338-368.

Hoffman, Claduia. Grev Hakkı ve Uluslararası Çalışma Örgütü. İstanbul: Frederich Ebert Vakfi, 2014.

Hoffman, Claudia ve Norbert Schuster. "It ain't Cover Till It's Over: The Right to Strike and the Mandate of the ILO Committe of Experts Revisited". ILO, Working Paper No: 40, 2016: 1-37.

Hoffman, Claudia ve Norbert Schuster. "Some Reflections on The Right To Strike and Its Treatment on The ILO”. ILO, Working Paper No: 28, 2014: 1-30.

ILO. $311^{\text {th }}$ Reports of Freedom of Association Committee. Vol: 81, Seri: B, No: 3, 1998.

ILO. Governing Body Report. Digest of Decisions and Principles of the Freedom of Association Committee. 2006.

ILO. Governing Body Report. Fifth Item on the Agenda: The Standards Initiative 323rd Session. 12-27 March 2015.

ILO. Governing Body Report. Matters Arising Out of Work of The International Labor Conference. International Labour Conference 317th Session. 2013.

ILO. Minutes of the 316th Session of the Governing Body of the International Labour Office. Geneva: 316 ${ }^{\text {th }}$ Session. 2012.

ILO. Minutes of the 317 th Session of the Governing Body of the International Labour Office, Geneva: 317 $7^{\text {th }}$ Session. 2013.

ILO. Report of Director -General. Democratisation and the ILO. Geneva: International Labour Conference, 79 ${ }^{\text {th }}$ Session. 1992.

ILO. Report of the Commitee on the Application of Standards: Submission, Discussion, and Approval. Record of Proceedings, No 27, International Labour Conference 101st Session. 2012.

ILO. Report of the Committee of Experts on the Application of Conventions and Recommendations. ILC 43 ${ }^{\text {rd }}$ Session, Part: 1, Report: 3, 1959.

ILO. Sixth Report of the International Labour Organisation to the United Nations. 1952.

ILO. "Uluslararası Çalışma Örgütü (ILO) Anayasası”. ILO internet sitesi, http:// www.ilo.org.

International Trade Union Confederation (ITUC). The Right to Strike and the ILO: The Legal Foundations. March 2014: 1-122.

Kaboğlu, İbrahim. Özgürlükler Hukuku. 6. Baskı, Ankara: İmge Kitabevi, 2002.

Kaya, Pir Ali. Uluslararası Sosyal Politika: Teorisi, Uluslararası Çalışma Normları ve Güncel Gelişmeler. Bursa: Siyasal Kitabevi, 2014. 
Kloosterman, John ve Littler Shareholder. "The Right to Strike: The ILO's Freedom of Association Convention". Ius Laboris Global Human Resources Lawyers Bulletin. 2013.

Maupain, Francis. "The ILO Regular Supervisory System: A Model in Crisis?”. International Organizations Law Review. 10/1 (2013): 117-165.

Novitz, Tonia. "Connecting Freedom of Association and Right to Strike: European Dialogue with the ILO and Its Potential Impact". Canadian Labour and Employment Law Journal. 15/3 (2010): 465-494.

Swepston, Lee. "Human Rights Law and Freedom Of Association: Development Through ILO Supervision". International Labour Review. 137/2 (1998): 169-194.

Vogt, Jeffrey S. "The Right to Strike and the International Labour Organisation". King's Law Journal. 27/1 (2016): 110-131. 


\title{
ILO: Crisis in Terms of Right to Strike
}

\author{
SEVDA KÖSE
}

\begin{abstract}
The purpose of this study is to examine whether the rigid objections made by the employers' group at the International Labor Organization Conference in 2012 on the right to strike led to a crisis the context of the International Labor Organization. For sixty years in the context of jurispurudence of ILO's superbody mechanicsm when it is thought that right to strike has been included as a part of freedom of association and at the same time, the right to collective bargaining, trade union rights and right to strike has been considered as a whole. This situation continued until 2012 ILO Conference. With a serious objection from the employers' group, the question of whether there was a crisis in the ILO regarding the right to strike began to come to the fore. This led to the questioning of the effectiveness of the ILO's superbody mechanism and at the same time the ILO's criticism of its coordination within its supervisory bodies.
\end{abstract}

Keywords: Right to strike, Right to organise, ILO, Crisis of ILO, Freedom of Trade Union Rights. 